\title{
Coğrafya Öğretmenlerinin İyi Öğretim Anlayışlarının incelenmesi*
}

\author{
Yavuz DEĞiRMENCi ${ }^{* *}$
}

Coğrafya Öğretmenlerinin İyi Öğretim Anlayışlarının Incelenmesi

\section{Özet}

Bu araştırmanın amacı, ortaöğretimde görev yapan coğrafya öğretmenlerinin kendi görüş, düşünceleri ve deneyimleri doğrultusunda iyi öğretim anlayışlarının incelenmesidir. Bu amaç kapsamında hâlihazırda görev yapan coğrafya öğretmenlerinin iyi ve ektili öğretim anlayışlarının neler olduğu, kendi bakış açılarından iyi öğretimi nasıl gördükleri, iyi ve etkili öğretim adına öğrencileriyle ne tür uygulama ve etkinlikler yaptıkları belirlenmeye çalışılmışır. Nitel araştırma yöntemlerinden olgubilim (fenomenoloji) deseni ile tasarlanan bu araştırma toplam 14 coğrafya öğretmeni ile yürütülmüştür. Araştırma sonucunda elde edilen bulgulara göre, coğrafya öğretmenlerinin mevcut öğretim anlayışları öğrenci merkezli, yapılandırmacı ve yaparak yaşayarak öğretim yaklaşımı şeklindedir. Ayrıca öğretmenlerin, iyi öğretimi desteklemek adına genellikle öğrencileri etkin ve aktif kılan uygulamalara yer verdikleri tespit edilmiştir. Bununla birlikte coğrafya öğretmenlerinin öğretim sürecinde geleneksel metotlara da başvurdukları görülmüştür.

Anahtar Kelimeler: Coğrafya Öğretimi, İyi Öğretmen, İyi ve Etkili Öğretim

\section{Giriş}

Bilim ve teknoloji alanında yaşanan hızlı değişimler, toplumları birçok açıdan etkilediği gibi, onların yapısını ve hedeflerini de etkilemektedir. Kuşkusuz bu etkinin yaşandığı alanlardan birisi de eğitim ve eğitimin yapısıdır. Yaşanan bu gelişmelerin aslında nihai hedefi toplumları refaha ulaştıra-

\footnotetext{
*Bu çalışma, Uluslararası Kültür ve Bilim Kongresi'nde sözlü bildiri olarak sunulmuştur.

** Yavuz DEĞiRMENCi, Dr. Öğr. Üyesi, Bayburt Üniversitesi, Eğitim Fakültesi, ydegirmenci@bayburt.edu.tr. ORCID ID orcid.org/0000-0003-3417-1775
}

A Study on the Concept of "Good Teaching" from the Perspective of Geography Teachers

Abstract

The aim of this study is to examine the concept of good teaching from the point of geography teachers who work in secondeducation; based on their opinions, thoughts and experienter it was tried to determine what kind of see good teaching from their point of viow, and what kind of practices and activities they do with their students in the name of good and effective teaching. This research, which was designed with phenomenology pattern of qualitative research methods, was carried out with a total of 14 geography teachers. According to the findings, the current teaching concepts of aphy teachers are student-centered, and apply construcsupport that make the students active. Besides, it was observed that geography teachers applied traditional methods in teaching process.

Key Words: Geography Teaching, Good Teacher, Good and Effective Teaching
ID orcid.org/0000-0003-3417-1775

Makale Gönderim Tarihi 05/11/2018

Makale Kabul Tarihi 29/03/2019 


\section{Yavuz DEĞiRMENCi}

cak ve yaşam standartlarını artıracak ilerlemeler olarak gerçekleşmesidir. Ancak toplumların sağlıklı bir şekilde gelişimlerini sürdürmeleri her yönüyle nitelikli bir eğitime ve nitelikli olarak yetiştirdikleri bireylere bağlıdır (Genç, 2000). Toplumların geleceklerini teminat altına alabilmeleri için eğitim önemli rol oynar. Eğitimde hedeflere ulaşabilmek için ise her açıdan çağın koşullarına uyum sağlamakla mümkün olabilir. Diğer bir ifadeyle, etkin bir eğitim öğretim yapılmadan toplumun ihtiyaç duyduğu ve geleceği şekillendirebilecek bireylerin yetiştirilmesi mümkün değildir. Bu nedenle devletler geleceğin mimarı olacak olan bireylere etkili ve iyi bir eğitim vermeyi amaçlar (Şahin, 2010).

Eğitim sürecinde "iyi ve etkili öğretim nedir" veya "iyi bir öğretmenin temel özellikleri nelerdir" şeklindeki sorular bu alanda yapılan çalışmalarda en sık karşılaşılan sorulardır. Ancak iyi öğretim veya etkili öğretim, içerisinde birçok parametreyi barındıran, farklı boyutları olan ve farklı açılardan tanımlanabilecek kavramlar iken (Ekiz ve Yiğit, 2006), iyi öğretmenin temel niteliklerini ortaya koymak ta bir o kadar zordur (Korthagen, 2004; İşmen ve Yıldız, 2005). Nitekim Şişman ve Acat (2003)'a göre bugün yetkin bir öğretmenin özellikleri konusunda herkesin hemfikir olduğu standartlar henüz oluşmamıştır. Ancak yine de bu kavramlara yakından bakıldığında, Harden ve Crosby (2000)'a göre öğretim zorlu ve karmaşık bir görev olmakla birlikte, iyi öğretmeni öğrencinin öğrenmesine yardımcı olan kişi olarak nitelendirmiştir. Reed ve Bergeman (1992) ise iyi öğretmenin özellikleri arasında öğrencilerle iyi ilişkiler kurabilen, eğitici sınıf ortamını hazırlayan ve sürdüren, etkili kararlar alabilen, kırıcı olmayan ve iletişim becerisine sahip gibi hususları saymaktadır. Etkili öğretimde öğretmenin bireysel nitelikleri (Öztürk ve Ünal, 1999), aktif öğrenmeyi destekleyen öğrenme ortamı ve uygulamaları (Barth ve Demirtaş, 1997) yer alırken, etkili öğretmenlerde ise iyi bir sınıf yönetim yeterliliğine sahip olmanın yanında (Dilekmen, 2008), düşünen, soru soran, eleştiren, gelişim ve yeniliklere açık, sürekli kendini yenileyen ve mesleğini seven kişilik özellikleri ön plana çıkmaktadır (Şen ve Erişen, 2002). Açıkgöz (2016)'e göre ise etkili ve çağdaş öğretmen, sevecen, kendine ve başkalarına değer veren, iletişim yönü güçlü, sınıf yönetim becerilerine sahip, düzenli, üretken, entelektüel, eğitimsel amaçlarından ödün vermeyen ve bilişsel yetenekleri gelişmiş öğretmenlerdir. Doğanay (2014) ise ideal bir öğretmende bulunması gereken nitelikleri sıralarken, öğretmenlerin mesleğine ilgili, öğretmeye hevesli, etik kurallara uyan, iletişim becerisi yüksek, sabırlı, planlı, saygılı ve kendini sürekli yenileyen bir kişiliğe sahip olması gerektiğini vurgulamıştır.

Weinstein ve diğ., (1986)'ne göre iyi öğretim, öğrencilere nasıl öğreneceklerini, nasıl hatırlayacaklarını, nasıl düşüneceklerini ve kendilerini nasıl güdüleyeceklerini öğretmeyi içerir. Kuşkusuz bunu da gerçekleştirebilecek olanlar eğitim-öğretim hizmetinin en temel unsurlarından biri olan öğretmenlerdir. Eğitim ve öğretmen bir birini tamamlayan unsurlar olmakla birlikte, öğretmenlerin rolleri de giderek artmaktadır. Ayrıca eğitimin niteliği, eğitim sistemi içerisindeki temel unsurlardan biri olan öğretmenlerin niteliğine bağııır. Kısaca iyi bir eğitim iyi ve nitelikli öğretmenler sayesinde gerçekleşebilir (Çelikten, Şanal ve Yeni, 2005; Karabağ, 2007; Ubuz ve Sarı, 2009; Çetinkaya, 2009). Küçükahmet (2007)'e göre iyi öğretmenler, ancak iyi öğretmen yetiştirme programlarında yetişirler. Bu programlar içerisinde öğretmenlik meslek bilgisi, alan bilgisi ve genel kültür bilgisi gibi çeşitli öğretmen yeterlilik alanları bulunmaktadır (Çelikten ve diğ., 2005; Dilekmen, 2008; Gurbetoğlu ve 
Tomakin, 2011; Karabağ, 2007; Şen ve Erişen, 2002; Şişman ve Acat, 2003; Yetim ve Göktaş, 2004). Bununla birlikte Harden ve Crosby (2000)'a göre iyi öğretmenin sahip olması gereken rolleri ise; bilgi sağlayııı, öğrenciler için rol model, kolaylaşııııı, değerlendirici ve planlayıcı olarak belirtmiştir. Benzer bir durum coğrafya öğretmenleri içinde geçerlidir. Çünkü coğrafya eğitiminin etkili ve verimli olabilmesi için öğretmenlerin öğretim sürecini iyi planlaması, teknoloji bilgilerinin yeterli olması, çağdaş yöntem ve teknikleri etkili kullanabilmesi, coğrafi bilgi ve becerilerin günlük yaşamla daha çok ilişkilendirilmesi, coğrafya derslerini sıkııı olmaktan çıkararak eğlenceli hale getirmesi önemlidir. Konuyla ilgili olarak Önal ve Güngördü (2008)'ye göre ulusal ve uluslararası yapılan pek çok çalışmada coğrafya biliminin teorik bilgileri aktaran bir ders olmaktan çıkarılması gerektiği konusu vurgulanmışır. Çünkü öğretim sürecinde öğretmenin aktif olduğu yöntemlerin kullanılması ve sadece teorik bilgilerin aktarılması dersi hem sıkıı hale getirmekte hem de öğrencilerde bilgi koleksiyonu algısı oluşturmaktadır. Lacoste (1998)'a göre coğrafya derslerinin sıkıı olmasında ve öğrencilerin ilgisizliği konusunda süreçte kullanılan yöntem, teknik ve stratejilerin önemli etkisinin olduğunu dile getirmiştir. Nitekim coğrafya derslerinde aktif öğrenme yöntemlerinin öğrencilerin akademik başarılarını artırdığı (Akşid ve Şahin, 2011) ve coğrafya dersine yönelik tutumları olumlu yönde etkilediği (Bilgi, 2010), coğrafya derslerinde deney materyallerinin kullanılması coğrafya derslerini eğlenceli hale getirmekle birlikte öğrencilerin merak duygusunu artırarak soyut kavram ve konuların yaparak yaşayarak öğrenilmesine katkı sağladığı (Kıııç, 2015; Karakuş, 2007) yapılan çalışmalarda vurgulanmıştır.

Araştırmayla ilgili alanyazın incelendiğinde "iyi ve etkili öğretim", "iyi ve etkili öğretmen" kavramlarılla ilgili olarak farkı bilim alanlarında ulusal ve uluslararası (Sünbül, 1996; Kızltepe, 2002; Erginer ve Dursun, 2005; Tok ve Sontay, 2006; Dilekmen, 2008; Ubuz ve Sarı, 2009; Gurbetoğlu ve Tomakin, 2011; Aypay, 2011; Işıktaş, 2015; Orakcı, 2015; Hobbel, 2003; Sanchez, 2007; Loeb, Soland ve Fox, 2013; Biesta, 2015; Malik ve Bashir, 2015; Grant, 2015; Donat, Knigge ve Dalbert, 2017) düzeyde pek çok çalışmanın yapıldığı görülmektedir. Ancak, bu alanlardan biri olan coğrafya bilimi alanında coğrafya öğretmenlerinin iyi ve etkili öğretim anlayışlarını ortaya koyan çalışmaların sınırlı düzeyde olduğu görülmüştür. Karabağ (2007), çağdaş ve işlevsel coğrafya eğitiminin ancak bu alanda iyi yetişmiş coğrafya öğretmenleri ile mümkün olabileceğini dile getirmiştir. Şahin (2010) ise coğrafya eğitiminin daha etkili ve verimli olabilmesi ve belirlenen hedeflere ulaşlabilmesi için geçmişi anlayan, bugünü kucaklayan ve geleceği öngören bir coğrafya öğretimine ihtiyaç olduğunu vurgulamıştır. Etkin bir coğrafya öğretimi ise ancak sürecin doğru bir şekilde planlanması ve uygulanmasından geçmektedir. Dolayısıyla araştırmanın problem cümlesi, coğrafya öğretmenlerinin eğitim-öğretim sürecindeki uygulama, etkinlik ve deneyimlerinden yola çıarak öğretmenlerin iyi ve etkili öğretim ile ilgili görüş ve düşüncelerinin incelenmesidir. Araştırmada ayrıca şu alt sorulara da yanıtlar aranmıştır:

a) Coğrafya öğretmenlerinin mesleklerinde kendi öğretim anlayışları nasııdır?

b) Coğrafya öğretmenlerine göre iyi öğretim nedir? 
Yavuz DEĞiRMENCi

c) Coğrafya öğretmenlerinin iyi öğretimi desteklemek amaçlı öğrencilerle yapmış oldukları uygulama ve etkinlikler nelerdir?

\section{Yöntem}

Bu araştırmada, nitel araştırma yaklaşımlarından biri olan olgubilim (fenomenoloji) deseni kullanılmıştır. Bu yaklaşım, günlük yaşamda farkında olduğumuz ancak derinlemesine ve ayrıntılı bir anlayışa sahip olmadığımız olgulara odaklanmak için uygun bir zemin oluşturur. Fenomenler aslında özün araştırılması olup, olgular, olaylar, deneyimler, algılar, kavram ve durumlar gibi çeşitli şekillerde karşımıza çıkabilir (Yıldırım ve Şimşek, 2011; Turgut, 2009). Fenomenolojik yaklaşım, aslında bireysel evrenin araştırıımasıdır. Yani bu yaklaşımın temelini bireysel deneyim ve tecrübeler oluşturur. Bu yaklaşımda veri kaynakları araştırmanın odaklandığı olguyu yaşayan kişilerin deneyim ve tecrübeleridir ve araştırmacı bunlara odaklanır (Büyüköztürk ve diğ., 2011; Baş ve Akturan, 2008). Smith ve Eatough (2007)'a göre ise olgubilim araştırması yaparken, derinlemesine analiz için küçük örneklem gruplarının tercih edilmesi, katılımcılarla görüşmelerin yapılması, katıımcı görüşlerinden elde edilen veriler gruplandırılarak belirli tema ve kategoriler altında toplanması ve son olarak katılımcıların görüşlerinin araştırmacı tarafından yorumlanması ve raporlaştırılması gibi aşamalara dikkat edilmesinin uygun olacağını ifade etmiştir. Bu bağlamda araştırmada coğrafya öğretmenlerinin kendi deneyim ve tecrübelerinden yararlanarak iyi ve etkili öğretimi nasıl tanımladıkları, iyi ve etkili öğretim adına ne tür uygulama ve etkinlikler yaptıkları ve kendi öğretim anlayışlarının neler olduğunu belirlemek amacıyla öğretmenlerin görüşlerine başvurulmuş ve deneyimlerinden elde edilen veriler içerik analizi ile çözümlenerek yorumlanmıştır.

\subsection{Veri toplama aracı}

Araştırmada coğrafya öğretmenlerinin kendi öğretim anlayışlarını belirlemek, iyi ve etkili öğretim adına yaptıkları hâlihazırdaki eğitimsel uygulamaları hakkında görüşlerini almak amacıyla nitel araştırma veri toplama yöntemlerinden görüşme tekniği kullanılmıştır (Yıldııım ve Simsek, 2011). Araştırmanın verileri ise uzman görüşü sonrasında araştırmacı tarafından geliştirilen yarıyapılandırılmıs görüşme formu kullanılarak toplanmıştır. Nitel görüşmelerin amacı, katılımcıların duyguları, düşünceleri, fikirleri ve davranışları gibi doğrudan gözlemlenemeyen şeylerin anlayışını sağlamaktır (Patton, 1990). Nitel araştırmalarda kullanılan görüşme tekniği, görüşülen kişilerin bakış açılarını, duygu ve düşüncelerini ve anlam dünyalarını derinlemesine anlamaya çalışmaktır (Kuş, 2009). Bu amaçla çalışmaya katılan öğretmenlerle ayrı ayrı görüşülerek araştırma problemleriyle ilgili veriler toplanmıştır.

\section{2. Çalışma Grubu}

Bu araştırma, 2017-2018 eğitim öğretim yılının güz döneminde Türkiye'de bir il merkezinde, ortaöğretim kurumlarında (Anadolu, Fen ve Teknik liselerden oluşan toplam 8 farklı kurum) görev yapmakta olan ve amaçlı örnekleme metoduyla seçilen 14 coğrafya öğretmeni ile yürütülmüştür. Görüşme yapılmadan önce öğretmelere görüşme hakkında kısaca bilgi verilmiş ve daha sonra 
görüşme gerçekleştirilmiştir. Çalışmaya katılan her bir öğretmenle yapılan görüşmeler ortalama 1520 dakika sürmüştür. Araştırmanın çalışma grubuna ait veriler Tablo 1'de verilmiştir.

Tablo 1. Çalışma Grubunun Özellikleri

\begin{tabular}{llll}
\hline \hline Hizmet Yılı & Bayan & Erkek & Toplam \\
\hline 1-4 yıl arası & 3 & 2 & 5 \\
5-9 yıl arası & 2 & 2 & 4 \\
10-14 yıl arası & 1 & 1 & 2 \\
15 ve üzeri & - & 3 & 3 \\
Toplam & 6 & 8 & 14 \\
\hline
\end{tabular}

Araştırmaya katılan coğrafya öğretmenlerinin öğretmenlik deneyimleri 1 ile 32 yıl arasında değişmektedir. Tablo 1 incelendiğinde, çalışma grubu 6 bayan ve 8 erkek olmak üzere toplam 14 öğretmenden oluşmaktadır. Çalışmada 5 öğretmen 1-4 yıl arasında öğretmenlik deneyimine sahipken, 4 öğretmen 5 ile 9 yıl, 2 öğretmen 10 ile 14 yıl ve son olarak 3 öğretmen ise 15 yıl ve daha fazla öğretmenlik deneyimine sahip oldukları görülmektedir.

\subsection{Verilerin Analizi}

Araştırmada elde edilen veriler içerik analizi tekniği ile çözümlenmiştir. İçerik analizi, çeşitli söylemlere uygulanan bir takım metodolojik araç ve tekniklerin bütünü olarak tanımlanır. Bu analiz bir çeşit okuma olarak nitelenebilir. Söz konusu okuma sınırları belirlenmiş söylem örneklerinin çözümlenmesi esasına dayanır (Bilgin, 2014). İçerik analizinde amaç, elde edilen verileri belirli kavramlar ve temalar şeklinde bir araya getirmek ve bunları okuyucuların anlayacağı şekilde düzenleyerek yorumlamaktır (Yıldırım ve Şimşek, 2011). Ulaşılan veriler tablolarda yüzde (\%) ve frekans ( $f$ ) şeklinde sunularak yorumlanmıştır. Ayrıca görüşme yapılan öğretmenlerin görüşlerini yansıtmak amacıyla doğrudan alıntılara da yer verilmiştir. Bununla birlikte ulaşılan veriler iki alan uzmanına verilmiş ve uzmanlardan gelen dönütler sonrasında verilerin güvenirliğini sağlamak için Miles \& Huberman (1994) tarafından önerilen [Görüş birliği / (Görüş birliği + Görüş ayrılığı) x 100] formülü esas alınmış ve uyuşma oranı \% 90 olarak bulunmuştur.

\section{Bulgular ve Yorum}

Araştırmanın bu bölümünde coğrafya öğretmenleri ile yapılan görüşmeler sonrasında elde edilen bulgular, araştırmanın amacına yönelik oluşturulan sorular eşliğinde bu bölümde sırasıyla ve tablolar halinde verilmiştir. Tablo 2'de araştırmaya katılan coğrafya öğretmenlerinin kendi öğretim anlayışlarını yansıtan temalar verilmiştir. 
Yavuz DEĞiRMENCi

Tablo 2: Coğrafya Öğretmenlerinin Mevcut Öğretim Anlayışlarıyla illgili Görüşleri

\begin{tabular}{ll}
\hline \hline Kategori & $f$ \\
\hline Yaparak yaşayarak öğrenme yaklaşımı & 5 \\
Buluş yoluyla öğretim anlayışı & 4 \\
Yapılandırmacı yaklaşım & 3 \\
Öğrenci merkezli yaklaşım & 3 \\
Dersini sevdiren öğretim anlayışı & 3 \\
Geleneksel yöntem yaklaşımı & 3 \\
Öğretimin ilkelerine uygun yaklaşım & 3 \\
Disiplinli ve otoriter yaklaşım & 2 \\
Mesleğini seven ve işini önemseyen bir öğretim anlayışı & 2 \\
Olumlu okul ortamı ve atmosferinin oluşturulduğu anlayış & 2 \\
Öğretmenin rehber ve rol model olduğu anlayış & 2 \\
Öğrenmeyi öğrenme yaklaşımı & 1 \\
Yüksek motivasyon yer aldığı anlayış & 1 \\
Ödülün yer aldığı bir öğretim anlayışı & 1 \\
Ezberden uzak bir öğretim anlayışı & 1 \\
Teknoloji ile iç içe öğretim anlayışı & 1 \\
Öğrenciye değer veren bir yaklaşım & 1 \\
Geleneksel ve modern yaklaşımların harmanlandığı anlayış & 1 \\
\hline Güncellik ilkesinin ön planda tutulduğu anlayış & 1 \\
\hline
\end{tabular}

Coğrafya öğretmenlerinin öğretmenlik mesleklerinde kendi öğretim anlayışlarını yansıtan görüşlerinin analiz edildiği Tablo 2 incelendiğinde, öğretmenlerin öğretim anlayışları ve yaklaşımları içerisinde en fazla vurgulanan ve ön plana çıkan kategoriler sırasıyla "yaparak yaşayarak öğrenme yaklaşımı" ( $n=5)$, "buluş yoluyla öğretim anlayışı" $(n=4)$, "yapılandırmacı yaklaşım” $(n=3)$, "öğrenci merkezli yaklaşım" ( $n=3)$, "dersini sevdiren öğretim anlayış̧" $(n=3)$, "geleneksel yöntem yaklaşımı" $(n=3)$, "öğretimin ilkelerine uygun yaklaşım" ( $n=3)$, "disiplinli ve otoriter yaklaşım" ( $n=2)$, "mesleğini seven ve işini önemseyen bir öğretim anlayışı" ( $n=2)$, "olumlu okul ortamı ve atmosferinin oluşturulduğu anlayış" ( $n=2)$ ve "öğretmenin rehber ve rol model olduğu anlayış" ( $n=2)$ şeklinde olmuştur. Bununla birlikte öğretmenlerin görüşleri içerisinde en az vurgulanan öğretim anlayışları ise 
sırasıyla "öğrenmeyi öğrenme yaklaşımı" ( $n=1)$, "yüksek motivasyon yer aldığı anlayış” ( $n=1)$, "ödülün yer aldığı bir öğretim anlayışı" ( $n=1)$, "ezberden uzak bir öğretim anlayışı" ( $n=1)$, "teknoloji ile iç içe öğretim anlayışı" ( $n=1)$, "öğrenciye değer veren bir yaklaşım" ( $n=1)$, "geleneksel ve modern yaklaşımların harmanlandığı anlayış" $(n=1)$ ve son olarak "güncellik ilkesinin ön planda tutulduğu anlayış" ( $n=1)$ şeklinde ortaya çıkmıştır.

Aşağıda coğrafya öğretmenlerinin öğretim anlayışlarını yansıtan bazı görüşleri doğrudan alıntılar şeklinde verilmiştir. Buna göre katılımcı öğretmenlerden biri (Ö.9) konuyla ilgili olarak öğretim anlayışını "benim öğretim anlayışım yaparak yaşayarak öğretmektir. Öğrenciyi düşündüren, dersi öğrencinin kendi bilgileriyle birleştirerek kendilerinin bilgiyi keşfetmelerini sağlamaktır" şeklinde belirtmiştir. Diğer bir öğretmen ise (Ö.2), "ülkemizde yapılandırmacı yaklaşım her ne kadar 2000 yıllardan sonra eğitim ortamına kazandırımaya çalışılsa da öğretmenlik yıllarımda farkında olmadan bu yaklaşımı benimsemişim. Çünkü bu yaklaşımla ilgili biz öğretmenlere ilk defa bir seminer verdiklerinde fark ettim ki ben aslında bu yaklaşımı uyguluyormuşum" şeklinde görüş belirtmiştir.

Tablo 3: Coğrafya öğretmenlerinin iyi öğretime yönelik görüşleri

\begin{tabular}{ll}
\hline \hline Kategori & $f$ \\
\hline Yaşamda karşı̆̆ı olan ve gerçek yaşamla iç içe bir eğitim & 5 \\
Birden çok duyuya hitap eden uygulamaların yer aldığı eğitim & 5 \\
Öğrenci seviyesine, ilgi ve yeteneklerine uygun eğitim & 4 \\
Kalıcı öğretimin sağlandığı bir eğitim & 4 \\
Yaparak yaşayarak öğrenmenin gerçekleştiği bir eğitim & 3 \\
Öğrencinin aktif ve etkin olduğu bir eğitim & 3 \\
Sonuç değil süreç odaklı bir eğitim & 2 \\
Öğretmenin rehber olduğu bir eğitim & 1 \\
Ezbere dayalı eğitim yerine yaşama dayalı eğitim & 1 \\
Eşitlik ilkesine uygun bir eğitim & 1 \\
Alanında uzman ve alanına hâkim öğretmenin olduğu bir eğitim & 1 \\
Anlatım becerisi yüksek öğretmenin olduğu bir eğitim & 1 \\
Değer odaklı eğitim & 1 \\
Ülke ve toplumun yapısına uygun eğitim & 1 \\
Öğretimin somutlaştııılığı bir eğitim & 1 \\
Okul ortamında farklı uygulamaların yer aldığı eğitim & 1 \\
Davranış değişikliği gerçekleştirebilen bir eğitim & 1 \\
\hline
\end{tabular}


Yavuz DEĞiRMENCi

Öğrencinin sorgulama ve analiz edebilmesine imkân tanıyan bir eğitim

1

Tablo 3 incelendiğinde, coğrafya öğretmenlerine göre genel olarak "iyi öğretim" sırasıyla "yaşamda karşılığı olan ve gerçek yaşamla iç içe bir eğitim" ( $n=5)$, "birden çok duyuya hitap eden uygulamaların yer aldığı eğitim" ( $n=5)$, “öğrenci seviyesine, ilgi ve yeteneklerine uygun eğitim” ( $n=4)$, "kalıcı öğretimin sağlandığı bir eğitim" ( $n=4)$, "yaparak yaşayarak öğrenmenin gerçekleştiği bir eğitim" ( $n=3)$, "öğrencinin aktif ve etkin olduğu bir eğitim" $(n=3)$ ve "sonuç değil süreç odaklı bir eğitim" ( $n=2)$ şeklindedir. Diğer kategoriler ise sırasıyla "öğretmenin rehber olduğu bir eğitim" $(n=1)$, "ezbere dayalı eğitim yerine yaşama dayalı eğitim" ( $n=1)$, "eşitlik ilkesine uygun bir eğitim" $(n=1)$, "alanında uzman ve alanına hâkim öğretmenin olduğu bir eğitim" ( $n=1)$, "anlatım becerisi yüksek öğretmenin olduğu bir eğitim" ( $n=1)$, "değer odaklı eğitim” ( $n=1)$, "ülke ve toplumun yapısına uygun eğitim" ( $n=1)$, "öğretimin somutlaştırıldığı bir eğitim" ( $n=1)$, "okul ortamında farklı uygulamaların yer aldığı eğitim" ( $n=1)$, "davranış değişikliği gerçekleştirebilen bir eğitim" $(n=1)$ ve son olarak "öğrencinin sorgulama ve analiz edebilmesine imkân tanıyan bir eğitim" ( $n=1)$ şeklinde görüşlerini ifade etmişlerdir. İyi öğretimle ilgili olarak bazı öğretmenlerin doğrudan alıntılar şeklinde verilen görüşleri ise şu şekildedir: (Ö.14)'e göre "tek cümleyle açıklamak gerekirse kesinlikle öğretimde kalıılığın sağlandığı ve davranış değişikliğinin gözlenebildiği öğretimdir" şeklinde görüş bildirmiştir. Diğer bir öğretmen (Ö.3) iyi öğretim, "öğrenciye ezbere dayalı bilgi vermekten ziyade, yaşama dair bilgi vermektir. Verilen bilgiler öğrencinin gerçek yaşama aktarabileceği nitelikte olması gerekir. Sonuç olarak iyi öğretim yaşamla iç içe olan öğretimdir” şeklinde görüşünü dile getirmiş̧ir.

Tablo 4: Coğrafya Öğretmenlerinin İyi Öğretimi Desteklemek Amaçlı Öğrencilerle Yapmış OIdukları Uygulama Ve Etkinliklerle illgili Görüşleri

\begin{tabular}{ll}
\hline \hline Kategori & $f$ \\
\hline Çevre ve arazi gezisi & 4 \\
Öğrenciyi etkin ve aktif kılan uygulamalar & 4 \\
Araştırma ödevleri & 3 \\
Oyunla öğretim & 3 \\
Görsel Sunum & 3 \\
Ödüllü etkinlikler & 2 \\
Proje ve performans etkinlikleri & 2 \\
Kabartma harita etkinliği & 1 \\
Kodlama ile öğretim & 1 \\
Motive edici etkinlikler & 1 \\
\hline
\end{tabular}


Sözel ifadeler

Haritalar

Soru cevap

Merak uyandırıcı ifadeler

$\begin{array}{lr}\text { Keşfetmeye ve fark etmeye dayalı etkinlikler } & 1\end{array}$

$\begin{array}{lr}\text { Okula aidiyet duygusunu artıran etkinlikler } & 1\end{array}$

$\begin{array}{ll}\text { Benzetim tekniği } & 1\end{array}$

$\begin{array}{lr}\text { Gerçek yaşam örnekleri } & 1\end{array}$

$\begin{array}{ll}\text { Videolar } & 1\end{array}$

$\begin{array}{ll}\text { Test etkinlikleri } & 1\end{array}$

Zenginleştirilmiş etkinlikler 1

Yarışmalar 1

Akıllı tahta 1

Beyin firtınası 1

Tablo 4 incelendiğinde, coğrafya öğretmenlerinin eğitim sürecinde iyi öğretimi desteklemek amaçlı yapmış oldukları uygulama ve etkinlikler içerisinde en fazla vurgulananlar sırasıyla "çevre ve arazi gezisi" ( $n=4)$, "öğrenciyi etkin ve aktif kılan uygulamalar" $(n=4)$, "araştırma ödevleri" $(n=3)$, "oyunla öğretim" ( $n=3)$, "görsel sunum" ( $n=3)$, "ödüllü etkinlikler" ( $n=2)$ ve son olarak "proje ve performans etkinlikleri" ( $n=2$ ) ön plana çıkmaktadır. Daha az düzeyde kullanılan uygulama ve etkinlikler ise sırasıyla "kabartma harita etkinliği" ( $n=1)$, "kodlama ile öğretim" ( $n=1)$, "motive edici etkinlikler" ( $n=1)$, "sözel ifadeler" ( $n=1)$, "haritalar" $(n=1)$, "soru cevap" $(n=1)$, "Merak uyandırıcı ifadeler" ( $n=1)$, "Keşfetmeye ve fark etmeye dayalı etkinlikler" ( $n=1)$, "Okula aidiyet duygusunu artıran etkinlikler" ( $n=1)$, "Benzetim tekniği” ( $n=1)$, "Gerçek yaşam örnekleri” ( $n=1)$, "videolar" ( $n=1)$, "Test etkinlikleri" ( $n=1)$, "Zenginleştirilmiş etkinlikler" $(n=1)$, "yarışmalar" $(n=1)$, "akıllı tahta" $(n=1)$ ve son olarak ta "beyin fırtınası" ( $n=1$ ) şeklinde görüşlerini belirtmişlerdir. Konuyla ilgili olarak öğretmenlerin doğrudan görüşlerini yansıtan bazı ifadeler ise; (Ö.2) "öğretmenlik yıllarımda iyi öğretim adına öğrencilerin etkin rol aldığı etkinlikler gerçekleştiririm. Örneğin yeri geldiğinde köy kahvesi etkinliği, rap şarkısı etkinliği gibi oyunlarla bazı derslerimi işlemeye çalısııım. Bu etkinlikler sayesinde öğrenciler hem eğlenir, hem de ilgili coğrafya konularını daha iyi öğrenir" şeklinde görüşünü belirtmiştir. Diğer bir öğretmen ise (Ö.6) "iyi öğretim adına genelde derslerimde görsel sunumları kullanıyorum. Bununla birlikte haritalar, soru cevaplar ve sözel ifadeler en çok kullandığım tekniklerdir" şeklinde görüşünü ifade etmiştir. Başka bir öğretmen ise (Ö.3) "araştırma ödevleri ve proje etkinliklerini" kullanırken, diğer bir öğretmen de (Ö.14) iyi öğretim adına "çevre ve arazi gezilerinin coğrafya öğretiminde etkili olduğunu" dile getirmiştir. 
Yavuz DEĞiRMENCi

\section{Sonuç ve Öneriler}

Coğrafya öğretmenlerinin iyi öğretim anlayışlarının incelendiği bu araştırma bulgularına göre, coğrafya öğretmenlerinin mevcut öğretim anlayışları genellikle yaparak ve yaşayarak öğrenme yaklaşımı $(n=5)$, buluş yoluyla öğrenme yaklaşımı $(n=4)$, yapılandırmacı yaklaşım $(n=3)$ ve öğrenci merkezli yaklaşım ( $n=3$ ) anlayışı şeklinde olduğu görülmektedir. Bulut (2008) öğrenci merkezli uygulamalara ilişkin öğretmen görüşlerini incelediği bir araştırmasında, öğretmenlerin öğrenci merkezli etkinlikleri orta düzeyde uyguladıkları sonucuna ulaşmıştır. Polat (2018) ise benzer bir çalışmada sosyal bilgiler öğretmenlerinin öğrenci merkezli öğretim yöntem ve tekniklerini kullanmaya yönelik tutumlarını incelediği araştırmasında, öğretmenlerin kıdem değişkenine göre tutumlarının farklılaştığını ve düşük yaş düzeyinde olan öğretmenler lehine anlamlılık oluşturduğunu tespit etmiş̧ir. Tok ve Sontay (2006) yapmış oldukları bir çalışmalarında, öğrenme-öğretme yöntem ve tekniklerin, ders araç ve gereçlerinin ve sınıf atmosferinin iyi ve etkili bir öğretimin gerçekleşmesinde önemli olduğunu vurgulamışlardır. Başka bir çalışma sonucuna göre (Aypay, 2011) ise öğretim sürecinde iyi bir öğretmende bulunması gereken niteliklerden biri de öğretmenin etkili öğretim yöntemlerini bilmesi ve uygulaması gerektiği bulgusudur. Yine Artvinli (2010) ise, coğrafya öğretmenlerinin öğretme stillerinin öğrencilerin iyi öğrenmeleri üzerinde etkili olduğunu ifade ederken, aynı zamanda coğrafya öğretmenlerinin öğrenme-öğretme sürecinde öğrenci merkezli yaklaşımlara daha fazla yer vermesi gerektiğini dile getirmiştir. Araştırmada elde edilen bir başka bulgu ise coğrafya öğretmenlerinin mevcut öğretim anlayışları içerisinde öğrenci merkezli öğretim yaklaşımlarıyla birlikte geleneksel öğrenme yaklaşımlarının da yer aldığı görülmektedir. Bu bulguyu destekler nitelikte, Aybek (2015), Aybek ve Aslan (2015) öğretmen görüşlerine dayalı yürüttüğü çalışmalarında öğrenme-öğretme sürecinde öğretmenlerin çoğunlukla öğrenci merkezli yöntem ve teknikleri uyguladıkları, ancak süreçte öğretmen merkezli uygulamalara da yer verdiklerini tespit etmiştir. Artvinli (2010) ise coğrafya öğretmenlerinin öğretme stillerini incelediği çalışmasında, coğrafya öğretmenlerinin öğrenme-öğretme süreçlerinde ezbere dayalı ve öğretmen merkezli pasif öğretme stillerini tercih ettiklerini ifade etmiştir. Temizöz ve Özgün-Koca (2008) matematik öğretmenleriyle yaptıkları bir çalışmada araştırmaya katılan öğretmenlerin çoğunluğunun hâlihazırda geleneksel yöntemleri (soru-cevap ve düz anlatım) kullandıklarını tespit etmişlerdir. Benzer bir şekilde Demirkan ve Saraçoğlu (2016) da öğretmenlerin öğretim sürecinde tercih ettikleri yöntem ve teknikler içerisinde çoğunlukla geleneksel metotlardan bir olan düz anlatım tekniğine başvurduklarını belirtmişlerdir. Ayrıca Bardak ve Karamustafaoğlu (2016) pedagojik alan bağlamında fen bilimleri öğretmenlerinin kullandıkları yöntem ve tekniklerini inceledikleri bir çalışmasında çalışmaya katılan öğretmenlerin çeşitli nedenlerden dolayı geleneksel metotlara (düz anlatım ve öğretmen merkezli uygulamalar) bağlı kalarak derslerini yürüttüklerini belirtmişlerdir. Geleneksel metotların yaygın olarak kullanıldığı bu çalışma sonuçlarıyla bu araştırma sonucunda ulaşılan bulguların farklılaştığını söylemek mümkündür. Çünkü bu çalışmada her ne kadar bazı öğretmenler yer yer geleneksel metotlara başvursalar da araştırmaya katılan coğrafya öğretmenlerinin çoğunluğu öğrenci merkezli yaklaşımları tercih ettikleri görülmektedir. 
Araştırmada ulaşılan diğer bir bulgu ise coğrafya öğretmenlerine göre iyi öğretim, tanımlanırken çoğunlukla "yaşamda karşılığı olan, gerçek yaşamla iç içe bir eğitim" ( $n=5)$ ve "süreçte birden çok duyu organına hitap eden uygulamaların yer aldığı eğitim" $(n=5)$ şeklinde görüş belirtmişlerdir. Tomal (2009) günlük hayatta coğrafi bilgilerin kullanılma durumlarını incelediği bir çalışmasında, öğrencilerin coğrafya derslerinde edindikleri bilgilerin günlük yaşamda kullanılma durumlarının yüksek olduğunu (\% 61.6), ayrıca coğrafya biliminin günlük yaşamla daha fazla iç içe olması coğrafi bilgilerin anlamlı ve kalıc olmasını olumlu yönde etkileyebileceğini ifade etmiştir. Akınoğlu (2005) ise bir araştırmasında, coğrafi bilgilerin günlük yaşamla ilişkilendirilmediği durumlarda coğrafya dersinin sıkıcı bir ders olarak algılandığını belirtmiştir. Nitekim Tomal (2009) lise öğrencileriyle gerçekleştirdiği bir çalışmasında öğrencilerin coğrafi bilgi ve becerilerin günlük yaşamda kullanma konusunda "kısmen" yeterli olduklarını tespit etmiştir. Konu ile ilgili farklı çalışma bulguları (Özmen, 2003; Smith ve Siegel, 2004; Choi ve Johnnson, 2005; Taşdemir ve Demirbaş, 2010; Bal, 2015; Köse ve Gül, 2016; Güneş ve Öner, 2016) incelendiğinde okul ortamında edinilen bilgi ve derslerin günlük yaşamla ilişkilendirilmesinin önemli olduğunu vurgulamışlardır. Araştırma bulgusuna paralel olarak yapılan benzer çalışma sonuçları (Hodson, 1990; Çelebi ve Furtun, 2014; Şahin, 2015; Çığrık ve Özkan, 2016; Göçer, Arslan ve Çaylı, 2017; Ulusoy ve Altun, 2018; Bulut, 2018) incelendiğinde öğretim sürecinin planlanırken birden çok duyuya hitap eden uygulamaların önemli olduğu görülmektedir.

Bu araştırmanın dikkat çeken diğer bir bulgusu da, coğrafya öğretmenlerinin iyi öğretimi desteklemek amaçlı öğrencilerle yapmış oldukları uygulama ve etkinlikler içerisinde çoğunlukla "çevre ve arazi gezileri" ve "öğrencileri aktif kılan uygulamalar" olduğu görülmüştür. Coğrafya öğretiminde coğrafi bilgi ve becerilerin gerçek yaşam deneyimleriyle desteklenmesinin öğretimin etkililiği açısından pek çok faydası bulunmaktadır. Nitekim Kent, Gilbertson ve Hunt (1997)'a göre, saha ve çevre çalışmalarının coğrafya öğretimine olan katkıları konusunda çoğu coğrafya eğitimcisi hemfikirdir. Krakowka (2012) ise arazi gezilerinin öğrencilere anlamlı öğrenme deneyimleri için fırsatlar sunduğunu belirtmiştir. Bu konuda Fuller (2006) ve arkadaşlarının yapmış oldukları bir çalışmanın sonuçları incelendiğinde, coğrafya öğretiminde saha ve çevre çalışmalarının etkili olduğunu, bununla birlikte öğrencilere gerçek dünyadan deneyimler sunması, verilerin ilk elden elde edilmesi, öğrencilere farklı bakış açıları ve çeşitli beceriler kazandırmasının yanında sosyal katkılarının da olmasını desteklemektedir. Yine Behrendt ve Franklin (2014) yaptıkları farklı bir çalışma sonucuna göre eğitimde çevre çalışmalarının önemli olduğu, öğrencinin ilgi ve motivasyonunu artırdı̆̆ı bireylere deneyimsel öğrenme fırsatı sunarak onların üst düzey düşünme becerilerine katkı sağlayabileceğini tespit etmişlerdir. Yine Lai (1999) coğrafya öğretmen ve öğrencilerinin alan çalışmalarıyla ilgili deneyimlerini incelediği nitel bir çalışmasında benzer bulgulara ulaşmıştır. Coğrafya eğitiminde çevre ve alan çalışmaları öğrencileri sınıfın sıkıcı atmosferinden uzaklaştırarak onlara zengin öğrenme deneyimleri sunmaktadır. Özgen (2011) yaptığı bir çalışma bulgularına göre, coğrafya eğitiminde gezi-gözlem metoduyla yapılan eğitim ve öğretimin, geleneksel metotlara göre daha etkili olduğunu tespit etmiştir. Ayrıca Özgen araştırmasında, arazi çalışmalarının öğrencilerde sorumluluk bilincini artırabileceği ve öğrencilere coğrafi bakış açısı kazandırabileceği ifade etmiştir. Çalışkan (2011) ise bir çalışmasında bu konuya farklı bir bakış açısı kazandırarak gerçek arazi çalışmalarına 


\section{Yavuz DEĞiRMENCi}

alternatif olarak sanal arazi çalışmalarının öneminin giderek arttığını ifade etmiştir. Araştırma sonrasında şu önerilere yer verilebilir.

- Öğretmenlerin iyi ve etkili öğrenmeyi desteklemek amaçılı alternatif uygulama ve etkinliklerin neler olabileceğine dair farklı araştırmalar yapılması önerilmektedir.

- İyi ve etkili öğrenmeyi desteklemek amaçlı öğrenci merkezli uygulama ve etkinlikler konusunda öğretmenlerin etkili öğretim becerilerini geliştirmek için lisans ve sonraki eğitim dönemlerinde çeşitli eğitimlere tabi tutulabilir.

- İyi ve etkili öğrenmeyi desteklemek amaçlı coğrafya öğretmenlerinin farklı uygulamaları görme ve farklı bakış açıları kazanabilme amaçlı ortak bir paylaşım platformu oluşturulabilir.

- $\quad$ İyi ve etkili öğretimde öğrenci beklentileri de önemlidir. Bu nedenle iyi ve etkili öğrenmeyi desteklemek amaçı̈ı öğrenci beklentilerinin neler olduğunu ortaya koyan çalışmalar yapılabilir.

- Eğitim sürecinde iyi ve etkili öğrenmeyi desteklemek amaçlı öğrencilerin coğrafi bilgi ve becerilerini gerçek yaşamla ilişkilendirebileceği deneyimsel öğrenme metotlarına daha fazla yer verilebilir.

- Coğrafya eğitiminin etkili ve verimli olabilmesi adına arazi ve çevre gezileri önemlidir. Ancak bu konuda eğitim kurumlarının öğretmenlere ihtiyaç duyduğu gerekli desteklerin sağlanması önerilmektedir.

- $\quad$ İyi ve etkili öğrenmeyi desteklemek amaçlı günümüz teknolojik fırsatlarından nasıl daha verimli destek alınabileceği konusunda öğretmenlere çeşitli eğitimler verilebilir.

\section{Kaynaklar}

Açıkgöz, K.Ü. (2016). Etkili öğrenme ve öğretme. Biliş yayınları. İzmir.

Akınoğlu, O. (2005). Coğrafya Eğitiminin Etkililiği ve Sorunları. Marmara Coğrafya Dergisi. 12. İstanbul.

Akşid, F. ve Şahin, C. (2011). Coğrafya öğretiminde aktif öğrenmenin akademik başarı ve tutum üzerine etkisi. Batı Anadolu Eğitim Bilimleri Dergisi, 2(4), 1-26.

Artvinli, E. (2010). Coğrafya Öğretmenlerinin Öğretme Sitilleri. Elektronik Sosyal Bilimler Dergisi. 9, (33), 387-408.

Aybek, B. (2015). İlkokul ikinci sınıf İngilizce dersinin İngilizce öğretmenlerinin görüşlerine dayalı olarak değerlendirilmesi. Turkish studies. 10(15), 67-84. 
Aybek, B. ve Aslan, S. (2015). Sınıf öğretmenlerinin ilkokul 4. Sınıf trafik güvenliği dersi öğretim programına yönelik görüşlerinin değerlendirilmesi. Kastamonu eğitim dergisi. 24(2), 929-954.

Aypay, A. (2011). Behavioral Habits of Primary and Secondary Teachers and Their Perceptions on the Characteristics of a "Good Teacher". Elementary Education Online, 10 (2), 620-645.

Bal, A.P. (2015). Sınıf öğretmeni adaylarının rutin ve gerçek yaşam problemlerine yönelik başarı düzeylerinin ve görüşlerinin incelenmesi. Pegem eğitim ve öğretim dergisi, 5(3), 273-290.

Bardak, Ş. ve Karamustafaoğlu, O. (2016). Fen bilimleri öğretmenlerinin kullandıkları öğretim strateji, yöntem ve tekniklerin pedagojik alan bilgisi bağlamında incelenmesi. Amasya üniversitesi eğitim fakültesi dergisi, 5(2), 567-605.

Barth, J.L. ve Demirtaş, A. (1997). İlköğretim Sosyal Bilgiler Öğretimi, Yök, Dünya Bankası Yayınları Ankara.

Baş, T. ve Akturan, U. (2008). Nitel arastirma yontemleri NVivo 7.0 ile nitel veri analizi (1. baski). Ankara, Turkey: Seckin Yayincilik.

Behrendt, M., \& Franklin, T. (2014). A review of research on school field trips and their value in education. International society of educational research. 9, 235-245.

Biesta, G. (2015). How does a competent teacher become a good teacher? On judgement, wisdom and virtuosity in teaching and teacher education. In R. Heilbronn \& L. Foreman Peck (Eds), Philosophical perspectives on the future of teacher education (pp.3---22). Oxford: Wiley Blackwell.

Bilgi, M.G. (2010). Ortaöğretim kurumlarında coğrafya dersi kapsamındaki çevre konularının öğretiminde aktif öğretim yöntemlerinin rolü. TSA, 14(1), 271-290.

Bilgin, N. (2014). Sosyal bilimlerde içerik analizi. Siyasal kitapevi. Ankara.

Bulut, ì. (2008). Yeni ilköğretim programlarında öngörülen öğrenci merkezli uygulamalara ilişkin öğretmen görüşleri (Diyarbakır il örneği). Kuram ve uygulamada eğitim yönetimi. 56, 521-546.

Bulut, S. (2018). İşitme engellilere yabancı dil olarak Türkçe öğretiminde üç boyutlu teknolojilerin yeri. Millî eğitim dergisi, 218, 21-53.

Büyüköztürk, Ş., Çakmak, E.K., Akgün, Ö.E., Karadeniz, Ş. ve Demirel, F. (2011). Bilimsel Araştırma Yöntemleri. Pegem A Yayıncılık. Ankara.

Choi, H.J., \& Johnson, S.D. (2005). The effect of context-based video instruction on learning and motivation in on-line courses. The American Journal of Distance Education, 19(4), 215-227.

Çalışkan, O. (2011). Yer ve çevre bilimleri eğitiminde sanal arazi gezileri. Ankara üniversitesi eğitim bilimleri fakültesi dergisi, 44 (1), 91-106. 
Yavuz DEĞiRMENCi

Çelebi, S. ve Furtun, M.H.K. (2014). Yabancılara Türkçe öğretiminde eşadlı sözcüklerin doğru sesletiminde parçalarüstü birimlerin görünür hâle getirilmesi. Turkish studies. 9(9). 367-380.

Çelikten, M., Şanal, M. ve Yeni, Y. (2005). Öğretmenlik Mesleği ve Özellikleri. Sosyal Bilimler Enstitüsü Dergisi. 19 (2), 207-237.

Çı̆̆rık, E. ve Özkan, M. (2016). Bilim merkezinin fen bilimleri dersine yönelik tutuma ve öğrenme kalıcılı̆ı̆na etkisi. Millî eğitim dergisi, 209, 124-143.

Demirkan, Ö ve Saraçoğlu, G. (2016). Anadolu Lisesi Öğretmenlerinin Derslerde Kullandıkları Öğretim Yöntem ve Tekniklerine ilişkin Görüşleri. The Journal of International Lingual Socialand Educational Sciences. 2 (1), 1-11.

Dilekmen, M. (2008). Etkili Eğitim İçin Etkili Öğretmenlik. Atatürk Üniversitesi Sosyal Bilimler Enstitüsü Dergisi. 12 (2).

Doğanay, H. (2016). Coğrafya öğretim yöntemleri. Pegem yayınları. Ankara.

Donat, M., Knigge, M. ve Dalbert, C. (2017). Being a good or a just teacher: Which experiences of teachers' behavior can be more predictive of school bullying? Aggressive Behavior. 44, 29-39.

Ekiz, D. ve Yiğit, N. (2006). An Investigation of Student Teachers' Views of the Teacher Education Models from the Angle of Different Teacher Education Programs. Elementary Education Online, 5(2), 110-122.

Erginer, E. ve Dursun, F. (2005). Öğretim Elemanlarının Etkili Öğretim Becerilerinin Geliştirilmesine Yönelik Görüşleri. Eğitim ve Bilim. 30 (135), 11-22.

Fuller, I., Edmondson, S., France, D., Higgitt, D., ve Ratinen, I. (2006). International Perspectives on the Effectiveness of Geography Fieldwork for Learning, Journal of Geography in Higher Education, 30(1), 89-101.

Genç, S.Z. (2000). Bilgi Toplumunda Öğretmen Eğitimi. Kuram ve Uygulamada Eğitim Yönetimi. 6 (3).

Göçer, A., Arslan, S. ve Çaylı, C. (2017). Türkçe eğitiminde öğrenci gelişim durumunun belirlenmesinde süreç temelli tamamlayıcı ölçme değerlendirme yöntem ve araçları. Süleyman Demirel üniversitesi sosyal bilimler enstitüsü dergisi, 3(28), .263-292.

Grant, K. (2015). From Lists to Images: Exploring the Concept of the Good Teacher in Teacher Education. Journal of the Canadian Association for Curriculum Studies. 13 (1).

Gurbetoğlu, A. ve Tomakin, E. (2011). Sevilen ve Sevilmeyen Öğretmen Davranışlarına ilişkin Öğrenci Görüşlerinin incelenmesi. Ahi Evran Üniversitesi Eğitim Fakültesi Dergisi, 12 (1), 261276. 
Güneş, T. ve Öner, Z. (2016). Bağlam temelli öğrenme yaklaşımının öğrencilerin çevreye yönelik tutumlarına etkisi. International Journal of Social Sciences and Education Research, 3(1), 345355.

Harden, R.M., \& Crosby, J. (2000) AMEE Guide No 20: The good teacher is more than a lecturer the twelve roles of the teacher, Medical Teacher, 22 (4), 334-347.

Hobbel, N. (2003). Imagınıng The Good Teacher. Unpublished Doctoral Dissertation. Unıversıty of Wisconsın-Madison.

Hodson, D. (1990). A critical look at practical work in school science. School Science Review, 70 (256), 33-40.

Işıktaş, S. (2015). Öğretmen Adaylarının lyyi Öğretmen Olma ille ilgili Görüşleri. Hacettepe Üniversitesi Eğitim Fakültesi Dergisi. 30 (4), 119-131.

İşmen, A.E. ve Yıldız, S.A. (2005). Öğretmenliğe ilişkin tutumların özgecilik ve atılganlık düzeyleri açısından incelenmesi. Kuram ve uygulamada eğitim yönetimi. 42, 151-166.

Karabağ, S. (2007). Coğrafya öğretmenlerinin mesleki sorumlulukları. Kuram ve uygulamada coğrafya eğitimi (Edit. Karabağ, S. ve Şahin, S.) Gazi kitapevi. Ankara.

Karakuş, U. (2007). Deney yöntemi ve coğrafya öğretiminde kullanılması. Ahi Evran Üniversitesi Kırşehir Eğitim Fakültesi Dergisi, 8(1), 1-19.

Kent, M., Gilbertson, D.D. ve Hunt, C.O. (1997). Fieldwork in geography teaching: A critical review of the literature and approaches, Journal of Geography in Higher Education, 21(3), 313-332.

Kılınç, Y. (2015). Deney materyalleri uygulamaları ile eğlenceli coğrafya öğretimi. Doğu coğrafya dergisi, 34, 187-212.

Kızıltepe, Z. (2002). İyi ve Etkili Öğretmen. Eğitim ve Bilim. 27 (126), 10-14.

Korthagen, F.A.J. (2004). In search of the essence of a good teacher: towards a more holistic approach in teacher education. Teaching and Teacher Education 20, 77-97.

Köse, E.Ö. ve Gül, Ş. (2016). Sınıf öğretmeni adaylarının biyoloji bilgilerini günlük yaşamla ilişkilendirme düzeyleri. Amasya üniversitesi eğitim fakültesi dergisi, 5(1), 84-103.

Krakowka, A.R. (2012). Field Trips as Valuable Learning Experiences in Geography Courses, Journal of Geography, 111(6), 236-244.

Kuş, E. (2009). Nicel ve nitel araştırma teknikleri. Anı yayıncılık. Ankara.

Küçükahmet, L. (2007). 2006-2007 Öğretim Yılında Uygulanmaya Başlanan Öğretmen Yetiştirme Lisans Programlarının Değerlendirilmesi. Türk Eğitim Bilimleri Dergisi. 5 (2).

Lacoste (1998). Coğrafya savaşmak içindir (Çev. A. Arayıcı), Özne Yayınları, İstanbul. 
Yavuz DEĞiRMENCi

Lai, K.C. (1999). Freedom to Learn: A Study of the Experiences of Secondary School Teachers and Students in a Geography Field Trip, International Research in Geographical and Environmental Education, 8(3), 239-255.

Loeb, S., Soland, J. \& Fox, L. (2013). Is a Good Teacher a Good Teacher for All? Comparing ValueAdded of Teachers with Their English Learners and Non-English Learners. Educational Evaluation and Policy Analysis. In Press.

Malik, A.N. \& Bashir, S. (2015). Good teacher; student's perception about top qualities in health sciences. The Professional Medical Journal . 22 (5), 670-673.

Miles, M.B. \& Huberman, A.M. (1994). Qualitative data analysis: an expanded source book (2nd ed.). Thousand Oaks, CA: Sage Publications.

Orakçı, Ç. (2015). Şangay, Hong Kong, Singapur, Japonya ve Güney Kore'nin Öğretmen Yetiştirme Sistemlerinin İncelenmesi. Asya Öğretim Dergisi. 3 (2).

Önal, H. ve Güngördü, E. (2008). Coğrafya öğretiminde aktif öğrenme uygulamaları (Hava Kirliliği). BAÜ SBED 11(19), 60-74.

Özgen, N. (2011). Fiziki coğrafya dersi öğretim metoduna farklı Bir yaklaşım: gezi- gözlem destekli öğretim. Marmara coğrafya dergisi. 23, 373-388.

Özmen, H. (2003). Kimya öğretmen adaylarının asit ve baz kavramlarıyla ilgili bilgilerini günlük olaylarla ilişkilendirebilme düzeyleri. Kastamonu Eğitim Dergisi, 11(2), 317-324.

Öztürk, C. ve Ünal, S.(1999). Sınıf öğretmenlerinin sosyal bilgiler dersine karşı tutumu. Pamukkale Üniversitesi Ĕgitim Fakültesi Dergisi, 6 (6), 1-9.

Patton, M. Q. (1990). Qualitative evaluation and research methods. Newsbury, UK: London sage publication.

Polat, S. (2018). Sosyal bilgiler öğretmenlerinin öğrenci merkezli öğretim yöntem ve tekniklerini kullanmaya yönelik tutumlarının incelenmesi. Doğu coğrafya dergisi. 23(39), 83-94.

Reed, A.J.S. \& Bergeman, V. E. (1992). In the Classroom: An Introduction to Education on Guilford, CT: the Dushkin Publishing Group.

Sanchez, L. (2007). What Makes A Good Teacher: Are We Lookıng In The Right Directıon For Guidance?. Unpublished Doctoral Dissertation Presented to Educational Foundations and Leadership Department and the Graduate School of George Fox University.

Smith, J.A. \& Eatough, V. (2007). Interpretative phenomenological analysis. In E. Lyons \& A. Coyle (Eds.), Analysing qualitative data in psychology (pp. 35-50). Los Angeles, CA: Sage Publications. 
Smith, M.U. \& Siegel, H. (2004). Knowing, believing, and understanding: What goals for science education? Science \& Education, 13(6), 553-582.

Sünbül, A.M. (1996). Öğretmen Niteliği ve Öğretimdeki Rolleri. Kuram ve Uygulamada Eğitim Yönetimi. 2 (1).

Şahin, D. (2015). Zihinsel engelli bireylerde görsel sanatlar eğitiminin önemi. Sed, 3(2), 25-37.

Şahin, Ş. (2010). Coğrafyada çağdaş öğretim yöntemleri. Coğrafya eğitiminde kavram ve değişimler (Edit. Ramazan Özey ve Süleyman Incekara). Pegem yayınları. Ankara.

Şen, Ş. ve Erişen, Y. (2002). Öğretmen Yetiştiren Kurumlarda Öğretim Elemanlarının Etkili Öğretmenlik Özellikleri. Gazi Eğitim Fakültesi Dergisi. 22 (1), 99-116.

Şişman, M. ve Acat, M.B. (2003). Öğretmenlik Uygulaması Çalışmalarının Öğretmenlik Mesleğinin Algılanmasındaki Etkisi. Fırat Üniversitesi Sosyal Bilimler Dergisi. 13 (1), 235-250.

Taşdemir, A. ve Demirbaş, M. (2010). İlköğretim öğrencilerinin fen ve teknoloji dersinde gördükleri konulardaki kavramları günlük yaşamla ilişkilendirebilme düzeyleri. Uluslararası insan Bilimleri Dergisi 7(1).

Temizöz, Y. ve Özgün-Koca, S.A. (2008). Matematik öğretmenlerinin kullandıkları öğretim yöntemleri ve buluş yoluyla örenme yaklaşımı konusundaki görüşleri. Eğitim ve Bilim Dergisi, 33(149), 89-103.

Tok, A. ve Sontay, S. (2006). Mesleki Ĕgitimde Öğrenci Memnuniyeti ve Etkili Öğretim. Milli eğitim dergisi. 172, 106-115.

Tomal, N. (2009). Coğrafya derslerinde edinilen bilgilerin günlük hayatta kullanılma durumları. Kastamonu eğitim dergisi. 17(1), 229-240.

Turgut, Y. (2009). Verilerin kaydedilmesi, analizi, yorumlanması: nicel ve nitel. Tanrıöğen, A., (Ed.), Bilimsel araştırma yöntemleri. (s. 193-247). Ankara: Anı Yayıncılık.

Ubuz, B. ve Sarı, S. (2009). Sınıf Öğretmeni Adaylarının İyi Öğretmen Olma İle İlgili Görüşleri. Ondokuz Mayıs Üniversitesi. Eğitim Fakültesi Dergisi. 28, 53-61.

Ulusoy, M. ve Altun, D. (2018). Okul öncesi öğretmen adaylarının çocuk edebiyatı ve resimli çocuk kitapları ile ilgili metaforları. Elektronik Sosyal Bilimler Dergisi. 17(67), 1206-1221.

Weinstein, Claire E. ve Richard E. Mayer. (1986). "The Teaching of Learning Strategies", Handbook of Research on Teaching. 3rd edition. Edi: M. C. Wittrock. New York: Macmillan Company, pp. 315-327.

Yeşildere, S. (2015). The Characterıstıcs of A Good Mathematıcs Teacher in Terms of Students, Mathematıcs Teachers, and School Admınıstrators. i-Manager's Journal on School Educational Technology. 12 (3). 


\section{Yavuz DEĞiRMENCi}

Yıldıım, A. ve Şimşek, H. (2011). Sosyal bilimlerde nitel araştırma yöntemleri. Seçkin yayınları. Ankara. 